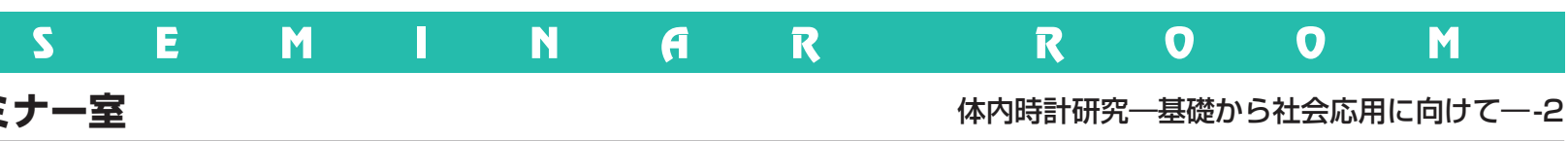

\title{
脊椎動物の季節感知機構の解明とその応用 動物たちの季節適応戦略の謎に迫る
}

\section{中山友哉 $* 1,2$, 中根右介*1,3, 吉村 崇*1,2,3}

${ }^{* 1}$ 名古屋大学大学院生命農学研究科動物統合生理学研究室, ${ }^{* 2}$ 基礎生物学研究所季節生物学研究部門, ${ }^{* 3}$ 名古屋大学トランスフォーマティブ生命分子研究所

はじめに

私たち日本人は古来より季節の変化を敏感に感じと り，四季を生活に取り入れ，その変化を楽しんできた. 春, 夏, 秋, 冬とはっきりした四季が繰り返される地域 では，季節に応じて旬の山菜や魚介類を取り入れた料理 を楽しんだり，お花見や花火大会といったように季節に 密着した行事がある。また，桜，梅，鶯といえば春，稲 刈りや松咠，秋刀魚といえば秋といったように，日本語 には季語が存在する。このように，われわれ日本人は季 節の変化を愛でる国民であるが，多くの動物にとって季 節の環境変化は，生命の危機を及ぼしうる重大な変化と いえる. 動物は繁殖, 渡り, 冬眠, 換羽など, その環境 変化にあった行動や生理機能を調節することで適応して いる．人間は，カレンダーや新聞を見ることで現在の暦 を把握することができるが，それらをもたない動物はど のように季節の変化を感知し，これから起きる変化を予 測しているのだろうか?

季節によって変動する環境因子には, 日長, 気温, 降 水量などが挙げられるが, 多くの動物は「日長」を指標 として季節の変化を感知し, その変化に適応しており, この性質は光周性（photoperiodism）と呼ばれてい る ${ }^{(1)}$. 気温や降水量は猛暑, 冷夏, 暖冬, 空梅雨など, 年によってばらつきがある情報である。一方，春分，夏 至，秋分，冬至は毎年同じ時期に訪れ，ばらつきの少な
い情報であるため，多くの動物が日長を季節の指標とし ているのは合理的である. しかし，動物がいかにして日 長の変化を感知しているか，その分子メカニズムは長い 間謎に包まれたままであった。

\section{ウズラから明らかになった光周性の制御機構}

ある生命現象のしくみを解き明かすには，多様な生き 物の中からその研究に最適な種を選ぶことが近道であ る.モデル動物の代表ともいえるマウスやショウジョウ バエは生物学の発展に多大な貢献してきたが，季節の変 化に対して明瞭に反応しないとされてきた。一方，鳥類 は高度に洗練された光周性を示すことが知られている。 多くの鳥類は空を飛ぶため, 非繁殖期には不要な精巣や 卵巣などの生殖腺を性成熟前の未分化な状態まで退縮さ せ，軽量化している。一方，繁殖期には子孫を残すため 繁殖状態に移行する必要がある，鳥類は繁殖期を迎える と，たった数週間で生殖腺を急速に発達させ繁殖活動に 備える。この変化は, 人工環境下でも日長を制御するこ とで再現することができ, 鳥類は光周性研究の優れたモ デルになりうると考えられてきた ${ }^{(2)}$. 鳥類のなかでも二 ワトリは昔から研究に用いられてきたが, 原産地が季節 の明膫でない熱带地域であることから明瞭な光周性を示 さない. 一方, ウズラは温帯である日本から朝鮮半島, 中国にかけて生息する渡り鳥であるため, 明瞭な光周性 


\section{$\bowtie$ ラム $\infty$}

小さなメダカを用いて大きな謎に挑む

メダカと聞いて多くの読者は地味で小さな魚のイ メージを思い浮かべるのだろうか. ペットショップ では色鮮やかな熱帯魚がひしめくなかで大型魚の餌 として販売されており，水族館では身近な魚すぎて あまりフィーチャーされない魚の一つであろう。ご く最近はメダカブームもあり，スポットライトが当た ることが多くなってきたが, その地味で小さな魚が大 きな謎の解明に役立つかもしれない.

ウズラやメダカは，日長が長くなることで春が到 来したことを認識するが，いったい動物はどのように 日長を測定しているのだろうか (臨界日長の謎)。ま た，季節によって変化する環境因子には日長のほか に温度があるが, 動物はどのように温度の変化を感 知して季節に適応しているのだろうか (温周性の謎). これらの謎はいまだわかっていないことが多い.メ ダカは, 日長が長くなり, 水温が上がる春に繁殖を 開始し, 日長が短くなり, 水温が下がり始める秋に 繁殖を停止する．人工環境下でも日長や水温を変化 させてやると，これらの刺激を敏感に感知し，繁殖を 開始したり，停止したりするため，メダカがどの季節 を感知しているのか評価しやすい大きな利点がある.
また, メダカは, 北は青森, 南は沖縄まで広い範囲 に生息しており，生息する地域によって季節変化に 対する応答性が異なることが知られていた．このこ とから，これらの地域差を利用することで臨界日長 や温周性の謎を解明できることが考えられた，日本 各地に生息するメダカを採集し，さまざまな日長や 温度に暴露したときに繁殖を開始するかどうか評価 したところ，繁殖を開始する日長および温度には明 瞭な地域差があり，北に生息するメダカは繁殖開始 により長い日長や高い温度を必要とすることが明ら かとなった。ささらに, これらの日長, 温度の応答性 の地域差を利用した遺伝学的な手法 (QTL解析, ゲ ノムワイド関連解析）や，遺伝子の発現を網羅的に 調べることができるRNA-seqを行ったところ，臨界 日長や温周性の現象に重要と思われる遺伝子をいく つか絞り込むことに成功できた．臨界日長や温周性 の謎の一端が明らかとなってきたものの, 謎の全容 をつかむにはまだまだやらないといけないことがた くさんがある．実験動物と言うと，多くの方がマウ スなどを想像するだろう。メダカを思い浮かべる方 はかなりの少数派だと思う。しかし，解き明かした い謎に対して最適な動物を用いることが解明への近 道となることも多い.
を示す. 1960～90年代にはウズラを用いて生理学的な 実験が行われ，視床下部内側基底部（mediobasal hypothalamus; MBH）の破壊実験により光周性が失われるこ と ${ }^{(3)}$, 長日刺激によって, 細胞の活性化マーカーである $\mathrm{c}-\mathrm{Fos}$ が MBHで強く発現すること ${ }^{(4)}, \mathrm{MBH}$ の電気刺激 により性腺刺激ホルモンの分泌が促進される(5)ことが示 されていたため, $\mathrm{MBH}$ が光周性の制御中枢であること が示唆されていた。

\section{1. 光周性を制御する甲状腺ホルモン}

ウズラにおいて生殖腺の発達には必ずしも連続した明 期は必要ではなく，短日条件下でも光感受相あるいは光 誘導相と呼ばれる特定の位相 (時間帯) に光が当たるこ とで, ウズラは長日と認識し, 生殖腺を発達させること ができることが知られていた ${ }^{(2)}$ ままた，この光感受相は 24 時間周期で現れることから，約 24 時間の内因性のリ ズム（概日リズム）を刻む体内時計，「概日時計」の関 与が示唆されていた。そこで，光感受相に光を照射した ウズラと，照射していないウズラから採取した $\mathrm{MBH}$ を 用いて，ゲノム情報の有無に関係なく研究を展開できる ディファレンシャル解析が行われ，光周性を制御する鍵 遺伝子が探索された. その結果, $\mathrm{MBH}$ の第 3 脳室周囲
に位置する脳室上衣細胞において発現するDIO2（2型 脱ヨウ素酵素）遺伝子が光照射により発現上昇するとと もに，DIO3（3型脱ヨウ素酵素）遺伝子が発現減少す ることが明らかとなった ${ }^{(6,7)}$. DIO2遺伝子は甲状腺ホ ルモン活性化酵素をコードしており，甲状腺から分泌さ れる低活性型の甲状腺ホルモンのチロキシン（thyroxine: $\mathrm{T}_{4}$ ) を, 活性型ホルモンのトリヨードチロニン（triiodothyronine: $\mathrm{T}_{3}$ ) に変換する酵素である。一方, DIO3遺伝子は甲状腺ホルモン不活性化酵素をコードし ており, $\mathrm{T}_{4}, \mathrm{~T}_{3}$ をそれぞれ不活性型のリバース $\mathrm{T}_{3}, \mathrm{~T}_{2}$ へ と変換する。つまり長日条件下では, $\mathrm{MBH}$ で $\mathrm{T}_{3}$ が局 所的に合成されるのである。脊椎動物の生殖腺は，視 床下部-下垂体-生殖腺（hypothalamus-pituitary-gonadal axis; HPG）軸によって制御されており，視床下部か ら分泌される性腺刺激ホルモン放出ホルモン（gonadotropin-releasing hormone; GnRH）によって，下垂体前 葉から黄体形成ホルモン (luteinizing hormone; LH) と 卵胞刺激ホルモン (follicle-stimulating hormone; FSH) が分泌され，生殖腺に作用することで発達する， $\mathrm{MBH}$ の最下部で下垂体と接している正中隆起 (median eminence; ME) には，GnRHニューロンの神経終末が投射 している．また，MEに位置するグリア細胞には甲状腺 
a

ホルモン受容体の発現が確認された ${ }^{(6)}$. 甲状腺ホルモン は脳の発達や可塑性に関与することが知られているた め, $\mathrm{MBH}$ で局所的に産生された $\mathrm{T}_{3}$ が， $\mathrm{GnRH}$ ニューロ ンの形態変化を促すことで $\mathrm{GnRH}$ の分泌を制御している 可能性が考えられた。電子顕微鏡でMEの超微細構造を 検討した結果，短日条件では $\mathrm{GnRH}$ ニューロンの神経終 末はグリア細胞によって包まれていたのに対し，長日条 件ではグリア細胞の包み込みが減少し, GnRHニューロ ンの神経終末が下垂体門脈と隣接する基底膜に直接接し ていた ${ }^{(8)}$ ．また，短日条件で飼育したウズラの脳内に $\mathrm{T}_{3}$ を投与したところ, これらの脳の形態変化と精巣の発達 を誘起することができたことから，MBHで局所的に合 成された $\mathrm{T}_{3}$ が, MEの形態を恋化させ，GnRHが分泌さ れることで, 精巣の発達が起こることが明らかとなっ た。つまり，春から夏にかけてMBHに打いて起こる DIO2 と DIO3のスイッチングによってMBHにおいて局 所的に活性型の甲状腺ホルモン $\left(\mathrm{T}_{3}\right)$ の濃度が上昇す ることが光周性制御の鍵であることが示された（図 1a).

\section{2. 春告げホルモン TSHの発見}

DIO2, DIO3が鍵遺伝子として発見された 2003 年当
図 1 - 脊椎動物の光周性を制御する情報伝 達経路の共通性と多様性

a 鳥類の光周性を制御する情報伝達経路. 脳深部光受容器によって感知された光情報 は, 下垂体隆起葉（PT）へと伝えられる. PTでは甲状腺刺激ホルモン (TSH) が誘導 され，上衣細胞で2型脱ヨウ素酵素 (DIO2) の発現が上昇する。その結果, $\mathrm{T}_{4}$ は活性型 甲状腺ホルモン $\mathrm{T}_{3}$ に変換される。 $\mathrm{T}_{3}$ は性腺 刺激ホルモン放出ホルモン $(\mathrm{GnRH})$ 神経 終末およびグリア細胞の形態変化を誘導す ることで, GnRHの分泌を促進する. b 哺乳 類の光周性を制御する情報伝達経路. $\mathrm{c}$ サク ラマスの光周性を制御する情報伝達経路.
時, 鳥類の研究ではゲノム情報の欠如が大きな障壁と なっていた。しかし，2004年 12 月になると，ニワトリ の野生原種と考えられている赤色野鵎のドラフトゲノム が解読されるとともに, 約 3 万 8 千個の転写産物の発現 量を一度に解析できるニワトリマイクロアレイが発売さ れた。 ウズラはニワトリと同じキジ目キジ科に属してお り近縁なため, DNA 塩基配列が高度に保存されている. そこでニワトリマイクロアレイを用いてウズラでゲノム ワイドなトランスクリプトーム解析が行われ, DIO2遺 伝子の発現を制御する遺伝子が探索された。短日条件に て飼育したウズラを長日条件に移行した際の時系列サン プルのマイクロアレイ解析によって，長日1日目の明期 開始から 14 時間後に，下垂体の付け根にある下垂体隆 起葉（pars tuberalis; PT）において甲状腺刺激ホルモ ン (thyroid stimulating hormone; TSH) $\beta$ サブユニッ 卜遺伝子 $(T S H B)$ の発現が誘導されることが明らかと なった ${ }^{(9)}$. TSHは $\alpha$ サブユニットと $\beta$ サブユニットから なるへテロ二量体のホルモンであるが, 機能解析の結 果, PTにおいて産生されたTSHが MBHに存在する $\mathrm{TSH}$ 受容体を介してDIO2遺伝子の発現を制御すること が明らかとなった。つまり，長日刺激によって PTで産 生されたTSHがウズラの脳に春を知らせ, 季節繁殖の 
開始の引き金となる「春告げホルモン」として働くこと が明らかとなった（図1a)。これまで甲状腺刺激ホルモ ン TSHはその名のとおり, 甲状腺を刺激し, 甲状腺ホ ルモンの合成, 分泌を促進するホルモンであるというの が常識であった．しかしわれわれのウズラの光周性の研 究から, TSHには「春告げホルモン」としての新しい 機能があることが明らかとなった，また，長い間機能が わかっていなかったPTが，日長の情報を伝達する重要 な中継地点であることも明らかとなった.

\section{3. ウズラの光周性を制御する脳深部光受容器}

哺乳類では, 眼が唯一の光受容器官とされているが, 鳥類を含む哺乳類以外の脊椎動物は松果体でも光を感知 していることが知られている。しかし，鳥類では，眼や 松果体を除去しても季節繁殖に影響はない ${ }^{(10)}$.また, 墨汁を頭皮の下に注入し, 光が脳媣部へ届かないように すると, 長日刺激による生殖腺の発達が阻害される ${ }^{(11)}$. 一方で, $\mathrm{MBH}$ の局所的な光刺激が生殖腺を発達させ る(12,13) ことがわかっていた。 これらのことから，眼や 松果体以外にも, 脳深部に光受容器が存在することが示 唆されていた。脊椎動物の眼の網膜には, 薄明視にかか わる桿体細胞と, 明所視にかかわる錐体細胞が存在し, これらの細胞には光受容分子として機能するロドプシン や錐体オプシンといったロドプシン類がそれぞれ含まれ ている.これらの形態視にかかわる光受容分子に加え, 最近の研究により非形態視に重要なピノプシンやVA-オ プシン，概日時計の調節にかかわるメラノプシンが新た に発見された ${ }^{(14 \sim 17)}$. OPN5（オプシン 5) も新規ロドプ シン類としてマウスの脳などから単離されていたもの の, その光応答性や機能は未知のままであった．われわ れはウズラの脳におけるロドプシン類の網羅的な発現解 析によって, OPN5が脳室周囲の脳脊髄液接触ニューロ ンに発現していることを報告した(18) (図 1a)。脳脊髄液 接触ニューロンはその形態が発生段階の眼の視細胞に似 ていることから, 数十年前より脳深部光受容器の候補と して考えられてきたため, 光周性の起点となる脳樑部光 受容器である可能性が考えられた，そこで次に，本来光 に反応しないアフリカッメガエルの卵母細胞にOPN5を 強制発現させ, 光応答性を検討した結果, OPN5 は短波 長の光に応答を示す光受容器であることが明らかになっ た。また，スライスパッチクランプ法による解析におい ても OPN5を発現する脳春髄液接触ニューロンは光受容 能があることが示された ${ }^{(19)}$. さらに OPN5を発現する 脳脊髄液接触ニューロンが春告げホルモン TSHが分泌 されるPTに投射していること, OPN5のノックダウン
により長日刺激で誘導されるTSHの合成が抑制される ことから，OPN5が鳥類における季節繁殖を制御する脳 深部光受容器であることが明らかとなった（図1a).

\section{光周性の制御機構の普遍性と多様性}

\section{1. 哺乳類の光周性制御機構}

一般的にマウスやラットは季節性が顕著でないため, 季節適応の研究に適していないと考えられてきた。しか し，日長や気温が制御されているはずの飼育環境下でも マウスは毎年冬になると繁殖効率が落ちるというわれわ れの経験から，マウスも潜在的には季節の変化に対して 応答する能力があると考えられた，そこで，ウズラで明 らかにした仕組みがマウスに拝いても保存されているか 否かを検討することとした，哺乳類では，眼が唯一の光 受容器であり, 眼で受容した光の情報は概日時計の存在 する視床下部の視交叉上核を通じて松果体に伝えられる ことで，松果体から夜間のみ，メラトニンが分泌され る. 哺乳類では松果体除去により光周反応が消失し, メ ラトニンの投与によって短日条件下で飼育したときと同 じ表現型を再現できることから, 哺乳類ではメラトニン が季節繁殖の制御に必須の役割を果たしている(20). し かし，哺乳類に㧍いてメラトニンがどのようにして GnRHの季節性分泌を制御しているかは謎だった。哺乳 類においてはメラトニンの受容体がPTに強く発現して いることが報告されていたことから ${ }^{(21)}$, メラトニンが PTに作用することでTSHの分泌を制御し，PTから分 泌されたTSHがDIO2/DIO3のスイッチングを制御して いる可能性が考えられた。そこでTSH受容体ノックア ウトマウス技よびメラトニン受容体ノックアウトマウス を用いて, DIO2/DIO3のスイッチングに対するメラト ニンの影響を検討した。その結果, TSH受容体および MT1メラトニン受容体のノックアウトマウスではメラ トニンによるDIO2/DIO3のスイッチングが起こらな かった. 以上の結果から, 哺乳類では眼で受け取った光 情報がメラトニンの分泌パターンへと変換された後, メ ラトニンがPTの MT1メラトニン受容体に結合するこ とで, PTからの春告げホルモン TSHの分泌を制御し, DIO2/DIO3のスイッチングが制御されることが明らか となった（図 $1 b)$.

\section{2. サケ科魚類の光周性の制御機構}

鳥類や哺乳類では, PTが光周性の中枢として働くこ とを紹介してきた。しかし，魚類には解剖学的にPTに 相同な部位が存在しないため, 魚類における光周性の中 
枢やその制御機構は不明のままであった。魚類において も光周性の制御に甲状腺ホルモンが重要であることはよ く知られている。そこでサクラマスにおいて季節繁殖の 制御に重要なTSH, TSH受容体, DIO2の発現部位を検 討してみたところ，血管囊（saccus vasculosus）と呼 ばれる器官の王冠細胞において日長の変化により発現変 動していることが明らかとなった (22)（図1c）。血管霅 は, 魚類に扔いてのみ確認されている器官であり, 視床 下部の最下部，下垂体の背側に位置する器官である. 17

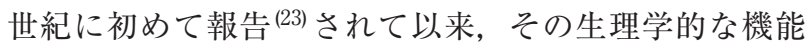
は明らかとなっていなかった。ささらにロドプシン類の発 現を検討したところ，少なくとも4種類のロドプシン類 が血管囊の王冠細胞に発現していることが明らかとなっ た (図1c)。これらの結果から, 血管囊の王冠細胞には 光受容器 (入力系) からホルモン (出力系) まで存在す ることが明らかになったため, 血管囊を取り出して, 短 日条件, もしくは長日条件にて培養したところ, 器官培 養下に㧍いて，血管囊が日照時間の変化に応答できるこ とがわかった。さらに，血管囊を除去したサクラマスは 本来生殖腺が発達するはずの短日条件下においても, 生 殖腺が発達しなかった。これらのことから, 血管囊が日 照時間の変化を感知し, 繁殖活動を制御する「季節セン サー」として働いていることが明らかとなった（図 1c).

以上，述べてきたように，動物の光周性の制御機構は 長い間謎に包まれていたが，われわれの近年の研究によ $り$, 鳥類, 哺乳類, 魚類の光周性を制御する情報伝達経 路が明らかとなり, 脊椎動物における光周性の制御機構 の普遍性と多様性が見えてきた。すなわち，哺乳類では 眼, 鳥類では脳深部光受容器, サクラマスでは血管囊が 光情報の入力系として機能しているほか, 光周性の制御 中枢は鳥類, 哺乳類ではPTに, サクラマスでは血管囊 に存在するなど, 多様性が認められた。一方で, 光周性 を制御しているTSH, DIO2, 甲状腺ホルモンなどの役 者には普遍性が認められた（図1）。

\section{2つの異なる働きをもつTSHが情報の混線を起こさ ない仕組み}

TSHは一般的に下垂体前葉（pars distalis; PD）から 分泌される糖タンパクホルモンとして古くから知られて 打り, 甲状腺に作用し, 甲状腺ホルモンの合成・分泌を 促すホルモンである。一方，前述したようにPT由来の TSHは脳に作用する場合に「春告げホルモン」という 全く異なる機能をもつが, PT と PDから分泌された $2 つ$ の TSHが身体の中で情報の混線を起こさない仕組みは
謎だったＰDにあるTSH分泌細胞は甲状腺刺激ホルモ ン放出ホルモン (thyrotropin-releasing hormone; TRH) 受容体および甲状腺ホルモン受容体を発現しており，視 床下部-下垂体-甲状腺（hypothalamus-pituitary-thyroid axis; HPT）軸によって制御されている(24).つまり PD のTSHはTRHによって正に, 甲状腺ホルモンによって 負の制御を受けていることでネガティブフィードバック ループを形成している，一方，PTにあるTSH分泌細胞 はPDにあるTSH分泌細胞と異なり, TRH受容体, 甲 状腺ホルモン受容体を欠いている。 またその代わり, PTのTSH分泌細胞はメラトニン受容体を密に発現して おり，メラトニンによって制御されていた ${ }^{(25 \sim 27)}$. 最近 の研究により, PT由来のTSHは脳に作用するだけでな く，末梢血中にも分泌されていることが明らかになった が，驚いたことに末梢血中に分泌されたPTのTSHは甲 状腺を刺激する能力を欠いていた ${ }^{(27)}$.そこで，この仕 組みを明らかにするために, PD と PTの TSHの構造を 検討してみたところ，両者の糖鎖修飾に違いがあること が明らかとなった．糖鎖修飾の違いは糖タンパクホルモ ンの半減期や生理活性に影響を及ぼすことが知られてい る ${ }^{(28,29)}$. たとえば，性腺刺激ホルモンであるLHは硫酸 基が付加した $N$ 結合型糖鎖が結合している一方，FSH はシアル酸修飾のある糖鎖が結合している．LHもFSH もパルス状に分泌される GnRHによる制御を受けている にもかかわらず，LHのみがパルス状の分泌を示す。こ れは, LHに付加した $N$ 結合型糖鎖の硫酸基が, 肝臟で 認識されると速やかに分解されるため半隇期が短い一方 で, FSHの $N$ 結合型糖鎖にはシアル酸が付加している ため分解が遅く半減期が長いためである. PD由来の

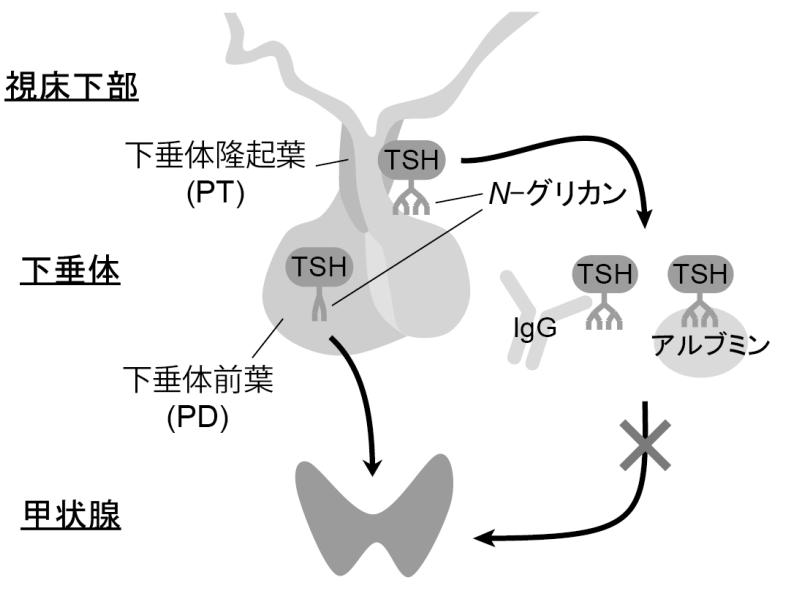

図 2 -甲状腺刺激ホルモンTSHが一人 2 役を演じる仕組み 下垂体隆起葉（PT）由来のTSHは組織特異的な $N$-グリカン修飾 があり，末梢血液中で免疫グロブリンやアルブミンと複合体を形 成する，複合体を形成することで血液中で生理活性が失われ，甲 状腺を刺激することを防いでいる. 
TSHには硫酸基が付加した 2 本鎖の $N$ 結合型糖鎖が結合 していたのに対し，PT由来のTSHにはシアル酸が付加 した 3 本鎖あるいは 4 本鎖の糖鎖が結合していることが 明らかとなった。興味深いことにPD と PT由来の $2 つ$ の TSHそのものの生理活性には違いはなかった．しか

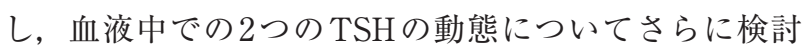
したところ，PT由来のTSHは血液中に分泌されるとそ の糖鎖構造を認識する免疫グロブリンやアルブミンと複 合体を形成することで血液中で活性を失い，体内で PD 由来の TSH との情報の混線を防いでいることが明らか となった(27) (図2).

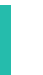

メダカから明らかとなった季節適応機構のメカニズ $\triangle$

\section{1. 季節適応研究の優れたモデル，メダカ}

これまで光周性の制御機構について紹介してきたが, 光周性の根源ともいえる概日時計を使った日長測定機 構, すなわち「臨界日長」の設計原理はいかなる動物に おいても未解明である。過去の研究から，ウズラは 11.5 時間の日長で飼育すると生殖腺を発達させないが，12 時間の日長で飼育すると生殖腺を発達させることが知ら れている(30).このようにウズラは30分の違いを見分け る精巧な体内時計をもっている。しかし，この謎を解明 するにあたり，ウズラでは遺伝学を使うのが困難である うえに, 遺伝子改変動物の作出が依然ルーチンワークと して行えないという限界があった，一方，メダカは，春 になると繁殖を開始し，秋になると繁殖を停止するよう に明瞭な季節性を示すうえに, 順遺伝学的手法を駆使で き，ゲノム編集技術が確立しているという大きな利点が あった。

\section{2. 季節によってダイナミックに変化するメダカの色覚 の役割}

われわれは現在，異なる緯度に由来するメダカ集団を
用いた順遺伝学的なアプローチで臨界日長の謎の解明に 取り組んでいる，その一連の実験のなかで，メダカは春 から夏は活発に泳ぎまわり，ほぼ毎日配偶行動をする が，冬は水槽の底でじっと息をひそめて厳しい環境をや り過ごすことに気が付いた。この行動の季節変化に興味 をもち, 光に対する応答性を夏のメダカと冬のメダカで 比較してみたところ, 冬のメダカは光感受性が低下して いることがわかった．また，メダカは繁殖期の春から夏 にかけて体色の橙色や赤色が濃くなる婚姻色を示すこと が知られているため，季節によって光感受性が異なるな ら, 婚姻色の見え方（色覚）も季節によって異なる可能 性が考えられた。そこで，3Dコンピュータグラフィッ クスを用いて婚姻色のヴァーチャルメダカと白黒の ヴァーチャルメダカを作成し, 実物のメダカにヴァー チャメダカを見せることで婚姻色に対する嗜好性を評価 した（図3a）。その結果，夏のメダカは婚姻色のヴァー チャルメダカに強い興味を示したのに対して，冬のメダ カは婚姻色, 白黒のいずれのヴァーチャルメダカにも興 味を示さないことがわかった（図3b)。このことから， メダカは冬と夏では光感受性や色覚が異なり, 季節に よって世界の見え方が異なっている可能性が考えられ た．そこで，メダカを冬の環境から夏の環境に移した際 の時系列サンプルにおいて, 眼におけるマイクロアレイ 解析を行った結果, 視覚をつかさどるロドプシン類やそ の下流の情報伝達経路の遺伝子の発現が冬には著しく低 下していたのに対し，夏には一斉に上昇することが明ら かとなった，婚姻色の橙色や赤色を主に感知するのは赤 錐体オプシンであるため, 赤錐体オプシンを欠損するメ ダカを用いて光に対する応答性や婚姻色の配偶者に対す る喏好性を評価したところ, 赤錐体オプシン欠損メダカ は野生型のメダカと比べて光応答性や配偶者嗜好性が低 下していた。これらの結果から，夏のメダカで観察され た行動が現れるためには，夏に赤錐体オプシンが発現誘 導されることが重要であることが明らかとなった ${ }^{(31)}$. a

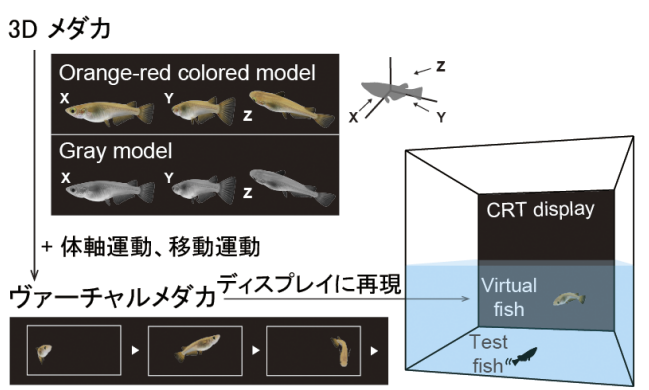

b

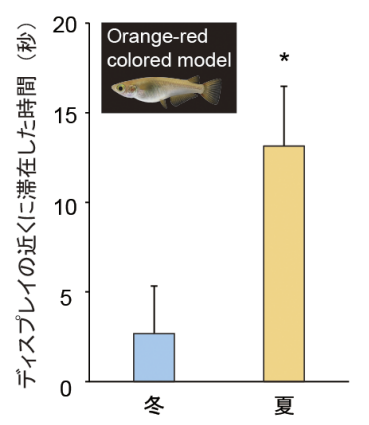

図 3 季節によってダイナミックに変化す るメダカの色覚

a ヴァーチャメダカを用いた体色に対する嗜 好性の評価. 形, 移動軌跡, 体軸運動など, 実物そっくりに再現したヴァーチャルメダカ をモニターに映して, 配偶者嗜好性試験を 行った. bヴァーチャルメダカの体色を変え て実験を行ったところ, 夏のメダカは婚姻色 のメダカに誘引されたのに対し, 冬のメダカ は誘引されなかった。 
a

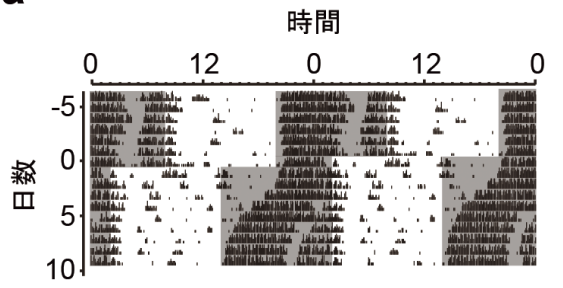

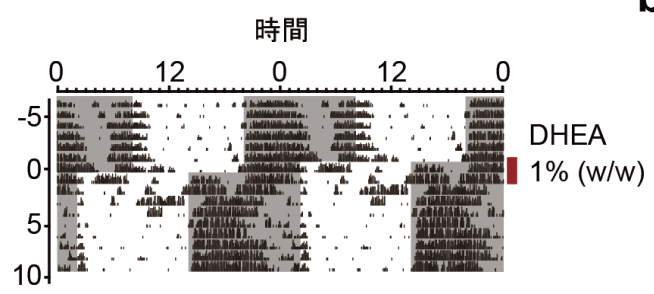

b

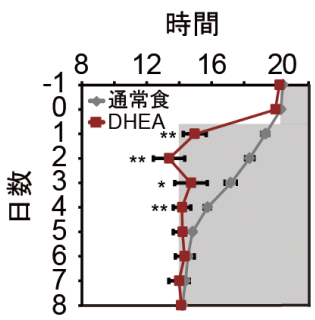

\section{図 4 『体內時計を調節する薬DHEA の発見}

$\mathbf{a}$ 明暗周期を 6 時間前進させた際のマウス回転輪活動リズム。グレーの網掛けは暗期を示す。夜行性のマウスは暗期に活動し，それが黒い バーとして記録される．明暗周期を前進させたときにDHEAを慨に混ぜて投与すると，新しい明暗周期にすぐに合わせて活動を開始した (右図). b 明暗周期を 6 時間前進させたときに通常食もしくはDHEAを与えたときのマウスの活動開始時間のプロットＤHEAを投与した マウスは，通常食を与えたマウスと比較して，時差ぼけが大幅に軽減した.

\section{概日時計を調節する化合物の創製}

概日時計の分子基盤は十数個からなる時計遺伝子・夕 ンパク質による転写・翻訳のネガティブフィードバック ループであり，これが約 24 時間周期で一周する．概日 時計はわれわれの身体のほとんどの細胞に存在し，それ ぞれの組織においてさまざまな遺伝子が一日のなかでリ ズミックに発現することで, 代謝や睡眠覚醒, ホルモン 分泌などさまざまな生理現象を制御している.

先述のとおり，季節繁殖動物が日の長さを測定する際 に概日時計は深く関与しているため, 概日時計を調節す る化合物を開発できれば，季節繁殖動物の繁殖を自在に 制御できる可能性が期待されている. また，近年の研究 から概日時計の不調が肥満やがんのリスクを高めること が明らかにされている，さらに概日時計の障害は季節性 気分障害などヒトの中枢性疾患との関連が知られている ことから，創薬の基盤研究にもなり得る，たとえば，時 計遺伝子の一つClockのドミナントネガティブ変異体で あるClock419マウスは概日時計の異常に起因してさま ざまな行動を示す．ヒトの双極性障害への影響を評価す るのに用いられる行動指標のマニア様行動がその一つで あり，時計夕ンパク質PERのリン酸化酵素カゼインキ ナーゼI $\delta / \varepsilon$ の阻害剤CK01 の投与によって改善されるこ とが報告されている(32).

われわれの研究グループは有機合成化学者, 計算科学 者との共同研究により, 時計タンパク質 $\mathrm{CRY}$ 標的と する化合物 KL001の構造活性相関を検討したところ, 側鎖の種類をC-Hカップリングによって変えることで, 概日リズムの周期を延長することも短縮することも可能 であることを報告した ${ }^{(33)}$. また，新薬の開発は膨大な コストと時間がかかり, 成功率も年々低下しているた め，近年注目を集めているドラッグリポジショニング (既存薬再開発) のアプローチも検討している. ヒトに
臨床応用されている 1,000 種類以上の承認薬の中から, 概日リズムに影響を与える化合物を網羅的に探索した結 果，全体の約 $5 \%$ に当たる承認薬がヒト由来の培養細胞 の概日リズムを変化させることを見いだした，そのなか で，概日リズムの周期を短縮するDHEAに着目した。 DHEA はヒトの血液中に最も豊富に含まれ, 男性ホル モン，女性ホルモンの前駆体となるステロイドホルモン である. DHEAは加齢とともに，減少するため，米国 では「若返りのサプリメント」としてスーパーで処方箋 なしで販売されている. DHEAはヒト由来の培養細胞 だけでなく，マウスの培養組織のリズムも短縮したた め, マウスに混慨投与した。 その結果, 行動リズムの周 期を短縮させるだけでなく, 12 時間明期 12 時間暗期の 明暗サイクルを 6 時間前進させた新規明暗サイクルへの 同調（時差ぼけの解消）についても必要な日数を半分以 下に短縮することにも成功した (34) (図4)。今後, 研究 をさらに発展させていくことで, 概日時計を調節する化 合物によって，季節繁殖やヒトの疾患を制御することが 可能となることが期待される.

\section{おわりに}

本稿では, 脊椎動物が季節の変化を感知し, 繁殖を開 始する情報伝達カスケードや，TSHが一人 2 役を演じる 仕組み，色覚の季節変化，体内時計を制御する分子の探 索などについて紹介してきた。春椎動物の季節感知機構 については理解が進んできたものの, 光周性の根源をな す概日時計を使って日長を測定する「臨界日長」の設計 原理や，動物が環境温度の変化を感知して季節の変化に 適応する仕組みは解明されていない，今後これらの謎を 解明していきたい. 
文献

1) W. Rowan: Nature, 115, 494 (1925).

2) B. K. Follett \& P. J. Sharp: Nature, 223, 968 (1969).

3) P. J. Sharp \& B. K. Follett: Neuroendocrinology, 5, 205 (1969).

4) S. L. Meddle \& B. K. Follett: J. Neurosci., 17, 8909 (1997).

5) H. Konishi, R. G. Foster \& B. K. Follett: J. Comp. Physiol. A Neuroethol. Sens. Neural Behav. Physiol., 161, 315 (1987).

6) T. Yoshimura, S. Yasuo, M. Watanabe, M. Iigo, T. Yamamura, K. Hirunagi \& S. Ebihara: Nature, 426, 178 (2003).

7) S. Yasuo, M. Watanabe, N. Nakao, T. Takagi, B. K. Follett, S. Ebihara \& T. Yoshimura: Endocrinology, 146, 2551 (2005).

8) T. Yamamura, K. Hirunagi, S. Ebihara \& T. Yoshimura: Endocrinology, 145, 4264 (2004).

9) N. Nakao, H. Ono, T. Yamamura, T. Anraku, T. Takagi, K. Higashi, S. Yasuo, Y. Katou, S. Kageyama, Y. Uno et al.: Nature, 452, 317 (2008).

10) T. D. Siopes \& W. O. Wilson: Poult. Sci., 53, 2035 (1974).

11) M. Menaker, R. Roberts, J. Elliott \& H. Underwood: Proc. Natl. Acad. Sci. USA, 67, 320 (1970).

12) J. Benoit: C. R. Soc. Biol. Paris, 118, 669 (1935)

13) K. Homma, M. Ohta \& Y. Sakakibara: "Photoinducible phase of the Japanese quail detected by direct stimulation of the brain." In: M. Suda, O. Hayaishi \& H. Nakagawa (eds.): "Biological rhythms and their central mechanism” , Elsevier/North-Holland Biomedical, 85-94 (1979).

14) T. Okano, T. Yoshizawa \& Y. Fukada: Nature, 372, 94 (1994).

15) B. G. Soni \& R. G. Foster: FEBS Lett., 406, 279 (1998).

16) I. Provencio, G. Jiang, W. J. De Grip, W. P. Hayes \& M. D. Rollag: Proc. Natl. Acad. Sci. USA, 95, 340 (1998).

17) S. Hattar, H.-W. Liao, M. Takao, D. M. Berson \& K.-W. Yau: Science, 295, 1065 (2002)

18) Y. Nakane, K. Ikegami, H. Ono, N. Yamamoto, S. Yoshida, K. Hirunagi, S. Ebihara, Y. Kubo \& T. Yoshimura: Proc. Natl. Acad. Sci. USA, 107, 15264 (2010).

19) Y. Nakane, T. Shimmura, H. Abe \& T. Yoshimura: Curr. Biol., 24, R596 (2014).

20) R. J. Reiter: Endocr. Rev., 1, 109 (1980).

21) H. Ono, Y. Hoshino, S. Yasuo, M. Watanabe, Y. Nakane, A. Murai, S. Ebihara, H.-W. Korf \& T. Yoshimura: Proc. Natl. Acad. Sci. USA, 105, 18238 (2008).

22) Y. Nakane, K. Ikegami, M. Iigo, H. Ono, K. Takeda, D. Takahashi, M. Uesaka, M. Kimijima, R. Hashimoto, N. Arai et al.: Nat. Commun., 4, 2108 (2013).

23) S. A. Collins: "Systeme of Anatomy," Thomas Newcomb. (1685).

24) M. W. Szkudlinski, V. Fremont, C. Ronin \& B. D. Weintraub: Physiol. Rev., 82, 473 (2002).

25) J. Bockmann, T. M. Böckers, C. Winter, W. Wittkowski, H. Winterhoff, Th. Deufel \& M. R. Kreutz: Endocrinology, 138, 1019 (1997).

26) M. Yamada, Y. Saga, N. Shibusawa, J. Hirato, M. Murakami, T. Iwasaki, K. Hashimoto, T. Satoh, K. Wakabayashi, M. M. Taketo et al.: Proc. Natl. Acad. Sci. USA, 94, 10862 (1997).

27) K. Ikegami, X.-H. Liao, Y. Hoshino, H. Ono, W. Ota, Y. Ito,
T. Nishiwaki-Ohkawa, C. Sato, K. Kitajima, M. Iigo et al.: Cell Rep., 9, 801 (2014).

28) J. U. Baenziger \& E. D. Green: Biochim. Biophys. Acta Rev. Biomembr., 947, 287 (1988).

29) C. A. Strott: Endocr. Rev., 23, 703 (2002).

30) B. K. Follett \& S. L. Maung: J. Endocrinol., 78, 267 (1978).

31) T. Shimmura, T. Nakayama, A. Shinomiya, S. Fukamachi, M. Yasugi, E. Watanabe, T. Shimo, T. Senga, T. Nishimura, M. Tanaka et al.: Nat. Commun., 8, 412 (2017).

32) R. Arey \& C. A. McClung: Behav. Pharmacol., 23, 392 (2012).

33) T. Oshima, I. Yamanaka, A. Kumar, J. Yamaguchi, T. Nishikawa-Ohkawa, K. Muto, R. Kawamura, T. Hirota, K. Yagita, S. Irle et al.: Angew. Chem. Int. Ed., 127, 7193 (2015)

34) T. K. Tamai, Y. Nakane, W. Ota, A. Kobayashi, M. Ishiguro, N. Kadofusa, K. Ikegami, K. Yagita, Y. Shigeyoshi, M. Sudo et al.: EMBO Mol. Med., 10, e8724 (2018).
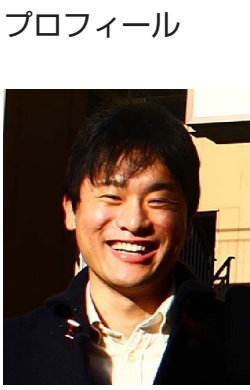

中山 友哉 (Tomoya NAKAYAMA)

$<$ 略歴 $>2012$ 年名古屋大学農学部資源生 物科学科卒業/2014年同大学大学院生命 農学研究科修士課程修了/同年 4 月積水义 ディカル株式会社入社 $/ 2016$ 年 4 月名古屋 大学大学院生命農学研究科博士課程在籍中 <研究テーマと抱負 $>$ メダカの季節適応機 構の解明. メダカがどのように季節の変化 を感知し, 適応しているかを解明し, 動物 たちが長年かけて獲得，洗練させてきた生 存戦略の謎に迫りたいです＜趣味＞日本全 国の川を巡って日本淡水魚を採取, 飼育す ること，ネイチャーアクアリウム

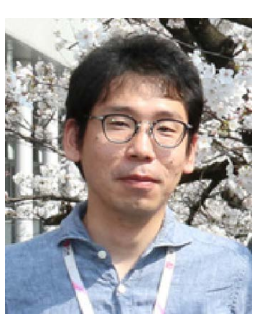

中根 右介 (Yusuke NAKANE)

$<$ 略歴 $>2012$ 年 3 月名古屋大学大学院生命 農学研究科卒業 / 2013 年 4 月田辺三菱製薬 株式会社入社 $/ 2016$ 年 9 月名古屋大学卜ラ ンスフォーマティブ生命分子研究所, 大学 院生命農学研究科在籍中 $<$ 研究テーマと抱 負 $>$ 概日時計を調節する化合物の創製，概 日時計破綻による疾患群の発症と進行の予 測＜趣味>テニス，パデル，ハイキング

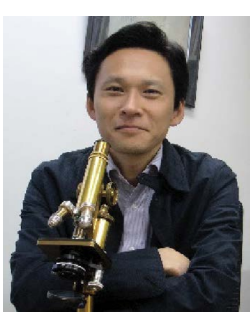

吉 村 崇 (Takashi YOSHIMURA)

<略歴>1996年名古屋大学大学院農学研 究科博士課程後期課程中退 /同年同大学農 学部助手 $/ 2005$ 年同助教授 $/ 2008$ 年同教 授 / 2013 年名古屋大学トランスフォーマ ティブ生命分子研究所教授, 基礎生物学研 究所客員教授，現在に至る<研究テーマと 抱負>動物とヒトの季節適応機構の解明と その制御<趣味>旅行, 博物館めぐり, ジョギング

Copyright (C) 2019 公益社団法人日本農芸化学会 DOI: 10.1271/kagakutoseibutsu.57.121 